\title{
Catalyzing Innovation
}

\section{The Future of Feed: Integrating Technologies to Decouple Feed Production from Environmental Impacts}

Asaf Tzachor

University of Cambridge, Center for the Study of Existential Risk, Cambridge, United Kingdom

\begin{abstract}
Population growth, an expanding middle-class, and a global shift in dietary preferences have driven an enduring demand for animal products. Since animal products are playing a vital role in human diets, their consumption is predicted to increase further. However, the great dependency of animal husbandry on global staple feed crop soybean; the environmental consequences of soybean production; and barriers for soy cropland expansion cast doubt on food system sustainability. The need to mitigate future demand for soy with other feed sources of similar nutritional profile, and thereby decouple food and feed production from ecological pressures, is compelling. Yet, the literature and science of sustainable agriculture is one of incremental improvements, featuring primarily, crop production intensification. A different, more profound approach to the design of feed systems is required to ensure sustainable food security. The question arises if alternative technologies exist to support such a design. This paper explores a particular novel configuration of four advanced technologies recently deployed in the region of Hengill, Iceland: light-emitting diode systems, advanced indoor photobioreactors, atmospheric carbon capture technology, and geothermal energy technology. In situ system analysis and data triangulation with scientific literature and data from independent sources illustrate the potential of these integrated technologies to produce algal-based animal feed. The analysis suggests that a highly sustainable soybean equivalent is technically attainable for feed purposes. The integrated system requires less than 1\% of arable land and fresh water compared with soybean cultivation and is carbon negative. In addition, it provides a pesticide- and herbicide-free cultivation platform. This new configuration provides one pathway for the future of feed.
\end{abstract}

Keywords: food security, feed, soybean, microalgae, alternative technology

\section{Introduction}

B

y 2030, 8.5 billion people will occupy the planet. $^{1}$ Of them, over 5 billion individuals are projected to live in cities. ${ }^{2}$ The share of the middle-class of the total world population is estimated to expand from 1.8 billion people in 2009 , to 3.2 billion by 2020 , and 4.9 billion people in $2030 .^{3}$ Future demographic trends and their associated changes in dietary preferences are set to drive a considerable increase in the demand for animal products. ${ }^{4-9}$

This paper takes interest in the consequences of the demand for animal products, and particularly, with the dependency of animal husbandry on soybean used as animal feed. It seeks to reduce the environmental pressures this dependency creates, especially on the availability of arable lands and potable water. ${ }^{10,11}$

While the literature and science of sustainable agriculture continue to propose incremental improvements in food and feed systems, a technological breakthrough is required to achieve sustainable food security.

This paper explores whether a particular novel integration of advanced technologies, recently deployed in a demonstration site in Hellisheiði geothermal park, Hengill area, Iceland, can produce a soybean-equivalent for animal feed, and thereby, reduce the environmental pressures of the livestock sector on natural resources. The study relies on scientific literature and independent measurements taken in situ, triangulated with official calculations of third-parties.

This paper is organized as follows: first, a brief description of the livestock economy illustrates the dependency of animal products in animal feed. Second, a concise presentation of soybean cultivation is used to highlight primary environmental pressures involved in soybean agriculture, which brings the sustainability of the food system into question. The paper then proposes that a radical innovation approach, not incremental, is required to design better performing feed systems decoupled from ecological pressures. The paper proceeds to assess an innovative configuration of advanced technologies, currently employed in the region of Hengill. The paper concludes with a comparison of this cultivation method with US soybean cultivation in two sustainability metrics. A discussion of this pathway for the future of feed summarizes the study. 


\section{The Livestock Economy}

According to the Food and Agriculture Organization, animal products have played a vital role in global food security and healthy nutritional requirements. ${ }^{7,12}$ Since the 1960 s, the daily intake of protein from meat, eggs, milk and dairy products has increased in high-income countries by $33 \%$. In low- and middleincome countries, the daily per capita availability of protein from animal products surged by $116 \%$ (both figures are expected to rise by 2030). ${ }^{13}$

Currently, animal products provide $34 \%$ of global protein intake and provide additional essential micro-nutrients. ${ }^{14,15}$ Recent predictions determine that animal products will continue to serve as a critical source of proteins in human diets (for clarity, "animal" is defined as "all food products from animal sources, including milk, eggs, cheese, chicken meat, beef, sausages, fish and seafood" $).{ }^{10}$ Accordingly, the demand for meat is expected to rise by $76 \%$ between 2005 and $2050 .^{5}$ Fischer et al. note that a demand increase is expected for other animal products. ${ }^{16}$

The livestock economy depends on a constant supply of animal food, referred to as feed, and so, future food and nutritional security hinges on a constant supply of certain staple crops used for animal husbandry.

\section{Staple Feed Crops}

Of the primary 100 global cultivated crops by land area, the top four items comprise approximately $50 \%$ of the total cropland. ${ }^{17}$ These four items-wheat, maize, rice and soybeanare therefore referred to as 'global staple crops' or 'the big four' ${ }^{16}$ Together, wheat, maize, rice and soybean command some 7 billion hectares of cultivation area. ${ }^{7}$ Of this, soybean consists of $17 \%$, equivalent to roughly 123.5 million hectares (Fig. 1). ${ }^{17,18}$

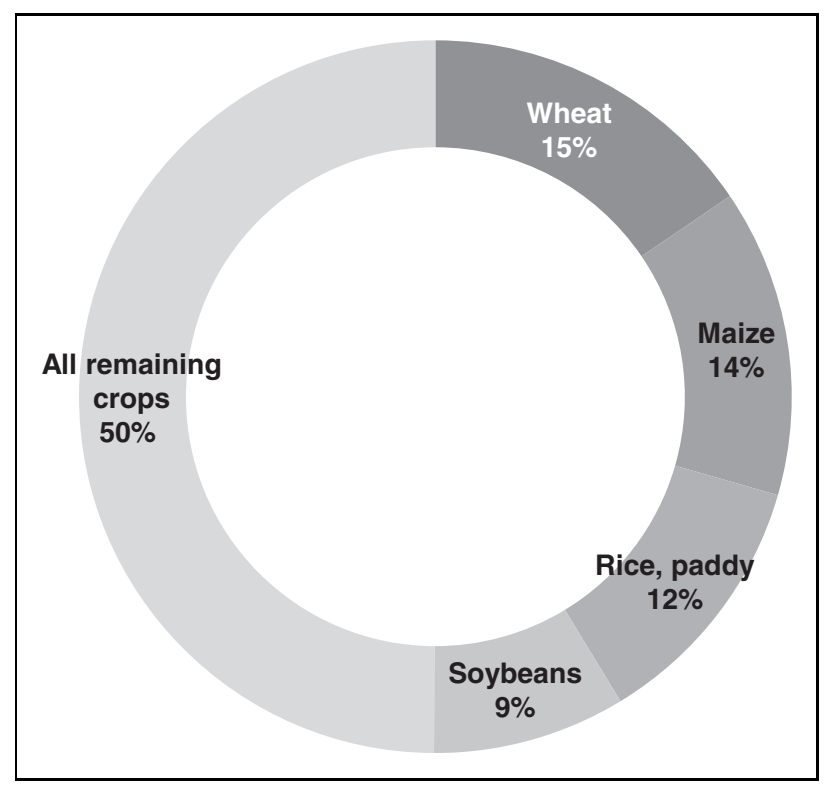

Fig. 1. Top one hundred global staple crops by area. ${ }^{17}$

\section{SOYBEAN}

Soybean (Glycine max) is the world's primary plant protein source, ${ }^{19}$ and over the last few decades it went through the greatest cultivation expansion of any global crop. ${ }^{20}$ The principal soy-producing countries are the US, Brazil, and Argentina, ${ }^{16}$ and the US is the largest single cultivator of soybean, accounting for over $25 \%$ of global output. ${ }^{21}$

According to World Wildlife Fund estimations, $85 \%$ of all soybeans are cultivated for feed purposes, primarily pigs and poultry, and predominantly in China, the EU, the US and Brazil-where the soybean serves as the primary protein source in the livestock economy. ${ }^{10,22}$ The WWF noted that every year, the average European consumes over $60 \mathrm{~kg}$ of soybean, mostly indirectly, by eating various animal products. ${ }^{10}$

According to the Global Forest Atlas, "due to the large international demand... the global soy harvest increased by $10 \%$ each year from 1989 to $1998 \ldots$.. Consumption in China has doubled from 26.7 million tons in 2000 to 55 million tonnes in 2009 ... across the whole of South America, production grew by $123 \%$ between 1996 and 2004". ${ }^{23}$

The nutritional profile of soybeans underpins this demand. Soybean oil and protein content combined account for $56 \%$ of dry soybeans by weight (DM). Protein makes about $36 \%$ and fat makes about $20 \% .^{24}$ The remainder contains $30 \%$ carbohydrates, $9 \%$ water and 5\% ash. Its essential amino acids composition is 3\% Leucine, $2.7 \%$ Lysine, 3.1\% Arginine, 2\% Valine, $1.7 \%$ Threonine, $2.1 \%$ Phenylalanine, $1.9 \%$ Isoleucine, $0.5 \%$ Methionine and $1 \%$ Histidine. The values of nutritional content of soybean are based on US soybean, as soy from this origin present higher content of essential amino acids than Brazilian and Argentinian soybean sources (three major soybean producers). ${ }^{25-28}$

Estimations register a necessary $80 \%$ growth in global soybean production between 2005 and 2050 to meet demand for animal products. ${ }^{16}$ This will entail an expansion of $32 \%$ in harvested areas by 2050 , more than any other global staple crop. ${ }^{16}$

\section{THE ENVIRONMENTAL CONSEQUENCES OF SOYBEAN}

Soybean is grown both in cold temperate regions (such as the US) and in warm and humid climates, in tropical and subtropical regions (such as Brazil, Argentina, China, India, and Paraguay). It is an open-field, sunlit, fertile-soil, predominantly rainfed, ${ }^{29}$ and sometime rotating-crop ${ }^{30}$ system, dependent on fresh water, fertilizers, and pesticides. ${ }^{16}$

World average soybean production stands at over 350 million tons per year, yielding an average of 28,542 hectograms per hectare. US soybean registers higher productivity levels, yielding 3,274 kilogram per hectare every year. ${ }^{17}$ Its cultivation requires an average of 2.5 pesticide spraying cycles every year, applying $8.6 \mathrm{~kg}$ of active ingredient per hectare each cycle, and one annual cycle of organic and synthetic fertilizers application (mostly phosphorous and potassium). The total US soybean emissions intensity (including land use change) is $0.94 \mathrm{~kg}$ of $\mathrm{CO}_{2}$ equivalent per one kilogram of biomass (DM). ${ }^{31}$

The global average water footprint of soybean is $2,144 \mathrm{~L} / \mathrm{kg}$ (green, blue and grey water combined). ${ }^{32}$ The more waterproductive US soybean requires $1,664 \mathrm{~m}^{3} / \mathrm{ton}$, or $1,664 \mathrm{~L} / \mathrm{kg}$ of biomass. $^{33}$ 


\section{TZACHOR}

Cultivation is subject to favorable weather conditions and is vulnerable to alternations in precipitation regimes, ${ }^{16,34}$ and therefore, to climate change. ${ }^{35}$ An open-field crop, the number of growing degree days, amount of sunshine and light intermittencies affect soy yield.

Using pesticide and fertilizer applications makes this type of cultivation system environmentally harmful, reducing biodiversity and impairing ecosystem services. ${ }^{36-38}$

In the primary soybean basket, the US, soil degradation is a concern. "In the continental US... between 2001 and 2010, 410,000 ha of grassland were converted to soy production", resulting in environmental degradation, according to the Global Forest Atlas, ${ }^{23}$ and in soil erosion, according to Nearing et al. ${ }^{39}$

Expanding production would require a strategy of yield intensification coupled with expansion of croplands, ${ }^{16,40}$ the latter would involve deforestation-a documented practice. ${ }^{41-45}$

Production intensification may prove a difficult task. Although progress has been achieved in improving crop yields, ${ }^{19}$ the rate of demand is estimated to outstrip the rate of yield improvement, ${ }^{21,46-48}$ and that of production. ${ }^{16,49}$ A $1 \%$ annual increase in soy yield, an observable figure, ${ }^{50}$ is insufficient to lessen global food security concerns.

Cropland expansion is no less challenging. ${ }^{12,51}$ According to the FAO, ${ }^{7,11}$ nearly one-third of the world's arable lands are moderately to exceedingly degraded (i.e., suffering erosion and loss of nutrients resulting in reduced soil fertility, due to intensive agriculture and removal of vegetation cover; see also Pimentel et al., ${ }^{52}$ Pimentel, ${ }^{53}$ and Quinton et al). ${ }^{54}$ In addition, the FAO stressed that there are scarce opportunities left for increasing agricultural areas. Bleakley and Hayes ${ }^{55}$ noted that "previously utilized methods of intensifying agriculture will soon no longer be an option due to the high impact trade-offs they have on the environment, including fragmenting natural habitats and threatening biodiversity, production of greenhouse gases from land clearing, fertilizers and animal livestock production, and nutrient run-off from fertilizer damaging marine, freshwater and terrestrial ecosystems"'. Nelson et al. ${ }^{56}$ and Tilman et al. ${ }^{57}$ indicated similar barriers for crop land expansion.

\section{Sustainable Agricultural Solutions for Food and Feed Systems}

The need to considerably improve agricultural methods and practices is well recognized in literature and in public policy. ${ }^{11,58,59}$ Yet, the science of sustainable agriculture is mostly one of incremental improvements, featuring, primarily, crop production intensification..$^{5,12,16,60-71}$ Some of these studies acknowledge that they leave approximately 350 million people in undernourishment conditions in $2050 .^{16}$

A different, more profound approach to the design of food and feed systems is desirable to dramatically enhance their sustainability profiles.

This need has not gone unnoticed. The $\mathrm{WWF}^{10}$ registered technological innovation in feed systems as an area of particular interest, arguing "we need to produce feeds with lower resource requirements", and highlighting-among other recent developments - new technologies in aquaculture for feed. In a similar vein, the $\mathrm{FAO}^{11}$ called to devise innovative feed systems, "to protect the natural resource base while boosting productivity". Recent research ${ }^{72}$ underscored several areas of technological innovation that are necessary to meet a growing demand for feed, while decoupling production from environmental impact.

The question arises if alternative technologies are readily available to support a fully sustainable feed-system design.

\section{Integrating Technologies for Resource-Efficient Algae Production}

Here, the paper explores an original configuration of four advanced technologies, or platforms, deployed in the region of Hengill, South West Iceland: advanced light-emitting diode systems, indoor closed photobioreactors, atmospheric carbon capture technology (also known as Direct Air Capture) and geothermal energy technology.

Three of the four technologies were not initially developed for feed-farming purposes. Hellisheidi heat and power plant intended to provide Iceland's domestic and industrial sectors with their electricity and direct heating needs. Advanced lightemitting diodes were concocted to efficiently emit light and are integrated in a wide catalogue of devices for various uses. Atmospheric carbon capture, which separates $\mathrm{CO}_{2}$ from ambient atmospheric air, proposes to play a role in climate change mitigation. The integration of the three for feed cultivation was made possible with the fourth technology: advanced, closed, indoor photobioreactor, the heart of the integrated system, made operational in early 2018.

Each platform is proprietary and listed under different entities. Each platform matured, technologically and commercially, in separate. Atmospheric carbon capture is still in relatively early development stages. ${ }^{73}$ The integration of all four is currently available only in Hellisheidi geothermal park.

The following sections introduce each technology and describe the overall cultivation system configuration. A review of the microalgae cultured in the system and a comparison of the environmental performance of the feed-system to soybean follows.

The analysis relies on scientific and technical literature, and on measurements taken on-site, triangulated with official calculations of third-parties. The latter is retrieved in the form of personal communication, conducted in the region of Hengill and in Reykjavik, Iceland. Data collection took place between November 2018 and February 2019.

While a comprehensive technical analysis of the four platforms lies outside the scope of this paper, a brief account of their functions on-site is provided.

\section{CLOSED INDOOR PHOTOBIOREACTORS}

Photobioreactors (PBRs) are apparatuses devised for the production of phototrophic microorganisms (e.g., microalgae). Closed indoor PBRs are comprised of closed cultivators (e.g., tubes or panels) of different shapes and sizes. To achieve optimum growth in PBRs, light and turbulence are the main factors for success. ${ }^{74}$ Closed indoor PBRs use electric light for irradiation $^{75}$ and various illumination technologies have been applied for PBRs in recent decades, including fluorescent lights, optical fibers and light emitting diodes. ${ }^{76-79}$ 
PBR systems are characterized by low pathogen contamination risks, low space requirements, and minimal ecologicalfootprint (if located on non-productive, non-arable land); almost no water losses, efficient $\mathrm{CO}_{2}$ utilization, high variability in regards to cultivatable species (nearly all microalgal varieties can be cultivated), high degree of control over culture processes, high biomass concentration, high efficiency of downstream processing; and for indoor PBRs, no dependence on weather conditions. ${ }^{74,75}$

About half of the microalgal dry weight is carbon, originating from $\mathrm{CO}_{2}$ photosynthetic fixation. To achieve a high photosynthesis rate (photosynthetic efficiency) in high-density microalgae photobioreactors, sufficient dissolved $\mathrm{CO}_{2}$ must be available to match the biological carbon demand. Straka et al. ${ }^{80}$ suggested injecting appropriate amounts of pure $\mathrm{CO}_{2}$ into microalgal cultures. This demands a complimentary carbon capture and delivery system. Such a system is discussed in the following.

To maintain optimal photosynthesis conditions and metabolism, a constant nutrient supply for the culture is a prerequisite. ${ }^{81}$ Closed photobioreactors offer a high level of control over culture processes so optimum temperature, $\mathrm{pH}$ levels, solution salinity, mixing, phosphorus and nitrogen concentrations can be kept in optimum ratios and ranges. ${ }^{74}$ According to Janssen et al. ${ }^{82}$ the productivity of PBRs is determined by the light regime inside the bioreactors. In a similar fashion, Kirk, ${ }^{83} \mathrm{Pulz},{ }^{74}$ and Suh and $\mathrm{Lee}^{75}$ maintained that light for photo-autotrophic life is the principal limiting factor in PBR environments. The next section discusses this aspect of the integrated system.

\section{LIGHT-EMITTING DIODES SYSTEMS}

Light-emitting diodes (LED) are artificial lighting devices, which provide spatial, temporal and spectral control of light. ${ }^{84-86}$ In a recent technical analysis of best available, high efficiency, light-emitting diodes for augmented photosynthesis, Ooms et al ${ }^{87}$ argued that readily available optical engineering technology holds the potential for production intensification of microalgae cultivation in PBRs. ${ }^{88}$ With regards to LED uses in PBR systems, Ooms et al. ${ }^{87}$ noted that the light regime " directly impacts the rate of photosynthesis and respiration. Controlling the cell density, light path, and mixing rates can result in optimal areal productivity and efficiency". 89

Based on an energy balance, taking into account energy-tolight LED efficiency and light-to-microalgae-biomass conversion efficiency (including biosynthesis and maintenance), Ooms at al. calculated the energy required per algal biomass to be $140 \mathrm{kWh}$ per $1 \mathrm{~kg}$ of biomass. ${ }^{87}$ This figure does not consider additional energy requirements of the cultivation system (PBR operations). According to on-site measurements of fluid dynamics, gas and liquid mass transfers demand $10 \%$ additional energy, or a total of $154 \mathrm{kWh}$ per $1 \mathrm{~kg}$ of biomass.

The controlled-environment agriculture (CEA) system allows 24 hours production for 330 operating days per annum (approximately $90 \%$ of the time; $10 \%$ is needed for system maintenance), or a total of 7,920 hours annually. Based on these figures, an annual production of 1 ton of biomass requires $19.4 \mathrm{~kW}$ per annum. These figures match the performance of the LED-PBR facility in Hellisheidi geothermal park.
Furthermore, as stated by Ooms et al. (2016), ${ }^{87}$ best available LED technology converts about $40 \%$ of the electrical energy to light. The residual energy $(60 \%)$ is converted into heat, which needs to be removed from the cultivation system to keep optimal LED performance (avoid LED overheat; extend LED lifespan), and maintain optimal cultivation temperature (algal strain dependent). Assuming $140 \mathrm{kWh}$ per $1 \mathrm{~kg}$ of biomass, at $40 \%$ conversion rate, $84 \mathrm{kWh}$ per kilogram $(60 \%)$ is residual energy (residual heat) and needs to be removed. This could be efficiently done by liquid-liquid heat exchange using cooling water (brackish or ocean water). This outlines the cooling requirements of the LED-PBR. While watercooling assessments are not included in this analysis, cooling demands require a nearby water source.

\section{ATMOSPHERIC CARBON CAPTURE}

Atmospheric carbon capture, also called Direct Air Capture (DAC) technology, has been an area of scientific and applied interest for some time ${ }^{90}$ and was suggested as a technicallyfeasible climate change mitigation instrument. ${ }^{91}$ It made significant progress in novel technical design and prototype systems in the last decade ${ }^{92,93}$ and received notable scientific attention more recently. ${ }^{94-96}$ One area of concern is the energy requirements of DAC systems, ${ }^{97}$ and if such demonstration technologies are connected to renewable energy sources, then DAC systems can be carbon-negative (for example, see Nikulshina et al.). ${ }^{98}$

An atmospheric carbon capture pilot plant (DAC plant), able to run on renewable energy source, was deployed in 2017 and is now operational in Iceland, as part of a Horizon 2020-funded CarbFix 2 project. It is the world's first carbon removal solution through direct air capture. The demonstration system is situated in ON Power Geothermal Park in Hengill. It draws ambient air and binds the $\mathrm{CO}_{2}$ within the air to a filter. When the filter is saturated with $\mathrm{CO}_{2}$ it is heated to approximately $100^{\circ} \mathrm{C}$, then the $\mathrm{CO}_{2}$ is released and collected as concentrated gas. The system is a net-negative carbon platform. In this facility, the majority of energy required for the process comes from low-grade heat (waste heat). The technology does not require a fresh water source. ${ }^{99}$

Based on pilot project reports and third-party assessments, to capture 1 ton of $\mathrm{CO}_{2}$-equivalent, the system requires approximately $2,000 \mathrm{kWh}$ for water heating and $650 \mathrm{kWh}$ of electricity; a total of $2,600 \mathrm{kWh}$. In the production process, the system produces about 1 ton of water for 1 ton of $\mathrm{CO}_{2}$. In large scale operations, the system would require $1 \mathrm{~m}^{2}$ of land to produce up to 30 tons of $\mathrm{CO}_{2}$-equivalent. In current installed capacity (pilot project), the system uses $1 \mathrm{~m}^{2}$ to capture 1 ton of $\mathrm{CO}_{2^{-}}$ equivalent. The pilot plant is connected to the geothermal energy source.

\section{GEOTHERMAL ENERGY TECHNOLOGY}

Geothermal energy is heat energy which originates from physical processes occurring in the internal structure of Earth's interior. ${ }^{100}$ Access to it depends on geological formations and is therefore unequally distributed on the planet's surface. For instance, the geographical location of Iceland is particularly favorable to harness geothermal energy for various uses. Barbier ${ }^{100}$ 


\section{TZACHOR}

noted that "Reykjavik is the only capital city of the world heated entirely by geothermal energy... (and) the first municipal district heating system using geothermal water was set up in Reykjavik in 1930." In 2002 some $90 \%$ of the population of Iceland lived in houses heated by geothermal energy.

Geothermal energy is exploited for two primary purposes, electric energy generation and direct uses (e.g., water heating, greenhouses). Geothermal electricity is produced at efficiency rates of $10 \%$ to $17 \%$ and geothermal $\mathrm{kWh}$ is costcompetitive with conventional sources of energy, in the range \$0.02-\$0.1 USD per kWh. Current geothermal technology enables producers to control its associated environmental impacts. ${ }^{101}$

Hellisheidi heat and power plant is Iceland's largest and newest power station and one of the largest geothermal power stations in the world, in terms of installed Megawatt capacity (Mexico and the US also host large systems). Since 2016, when generation expansion works concluded, Hellisheidi production capacity stood at approximately 303 Megawatts of electricity and up to 400 Megawatts of thermal energy. ${ }^{102}$

Two impartial Environmental Impact Assessments, based on the best knowledge available, were issued for Hellisheidi power plant. The first was conducted in 2002, and the second in 2005. Both assessments determined that the geothermal project does not have a significant impact on the environment. ${ }^{103}$ By the EIB, Hellisheidi Power Plant has negligible effect on water, air, flora, fauna, and biota of hot springs, as well as cultural remains, residential development and transport. The lands in Hengill area are moss-covered (roughly a quarter of the area is lava), has little or no vegetation and animal life is scarce. Land and climate conditions make the area unsuitable for open-air crop cultivation (i.e., non-productive, non-arable land).

\section{Microalgae to Mitigate Future Demand for Soy as Animal Feed, Cultivated in an Integrated LED-PBR-DAC, Based on Geothermal Energy}

Since early 2018, the integrated system has been cultivating natural strains of protein-rich high omega-3 marine microalgae for feed purposes (Fig. 2). In situ analysis was based on the cultivation of Nanochloropsis oculata.

Microalgae are commonly used for feed purposes. ${ }^{84,86}$ Literature recognizes them as important food and feed source. ${ }^{104-112}$ According to recent nutritional studies, microalgae can partially replace soybean in animal husbandry, and are therefore suitable for direct demand mitigation.

Gatrell et al. (2014) ${ }^{113}$ noted that broiler chicks, laying hens and weanling pigs can digest microalgal biomass incorporated into their diets at $7.5 \%$. Gatrell et al. $(2015)^{114}$ later demonstrated that $8-16 \%$ Nannochloropsis oceanica inclusion in broiler chick diets can produce a n-3 fatty-acid-enriched chicken meat.

Kim et al. ${ }^{115}$ indicated that $7.5-15 \%$ of soybean meal in pig or broiler chick diets can be replaced with defatted microalgae (Staurospira sp. and Desmodesmus sp.), with no animal health and food safety disturbances. Likewise, Austic et al. ${ }^{116}$ indicated that defatted diatom Staurosira could replace $7.5 \%$ of soybean meal in broiler chick diets.

Becker ${ }^{117}$ claimed that microalgae (Spirulina) up to a level of $10 \%$ can be included safely as a substitute for conventional proteins (including soy), in poultry rations. Evans et al. ${ }^{118}$ demonstrated that algae inclusion (Spirulina) in bird diet formulations of up to $16 \%$ (to replace about $60 \%$ of the soybean meal), has no harmful effect on performance.

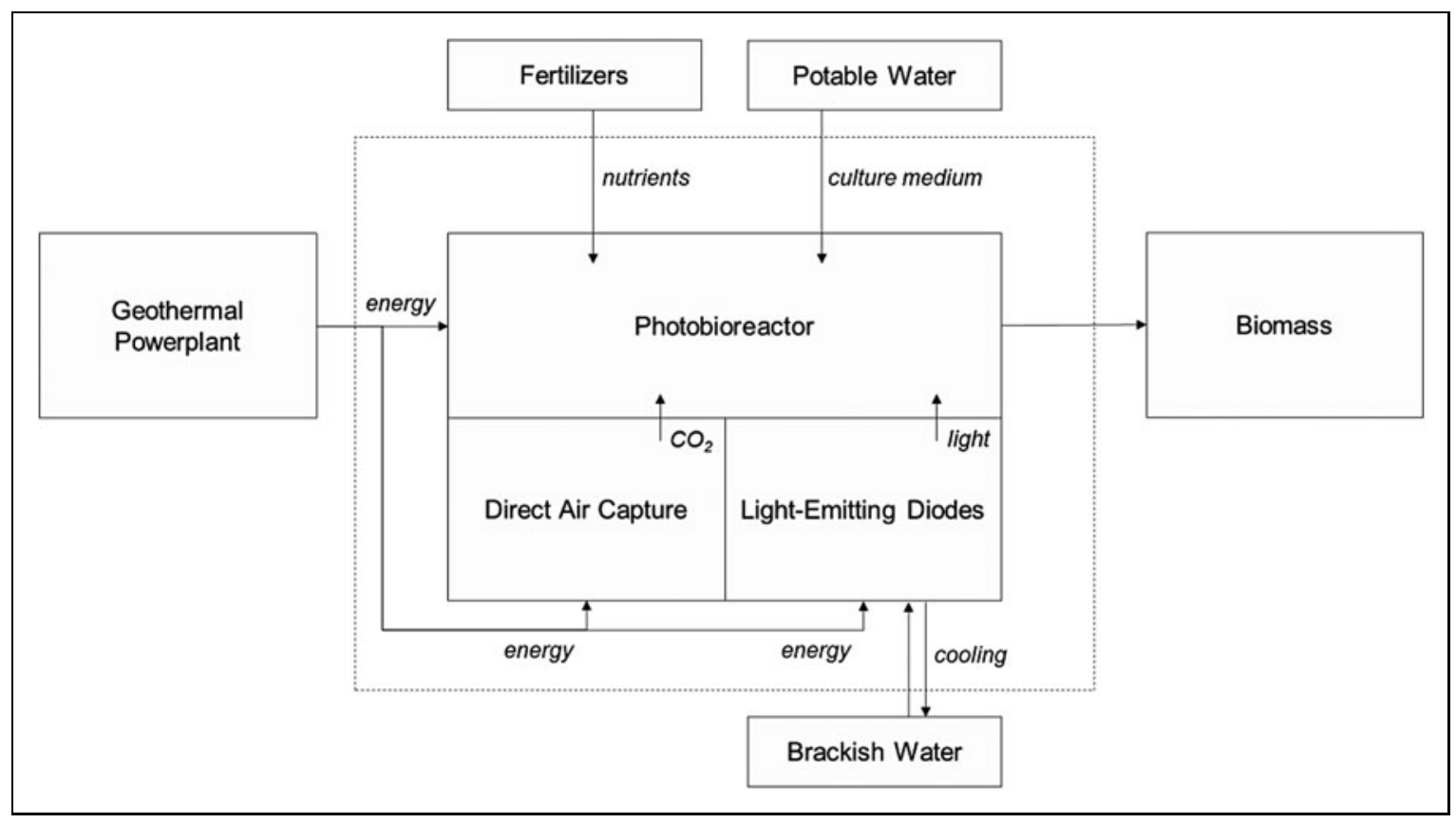

Fig. 2. Integrated system outline (in place and operational to produce $10,500 \mathrm{~kg}$ of biomass per year; DAC is a pilot project). 
A more recent study of meat quality (physico-chemical testing) to determine the effects of substituting soybean meal with Spirulina in poultry diets, found that a $50 \%$ substitution of soybean with microalgae shows insignificant or no changes in meat quality, and by some parameters, improved meat quality. ${ }^{119}$

As early as 1982, Yap et al. ${ }^{120}$ showed that a combination of Spirulina maxima, Arthrospira platensis and Chlorella can replace up to $50 \%$ of soybean in pig diets, with no harmful effects, while improving weight gain. Becker ${ }^{117}$ then argued that an upper limit for microalgae inclusion in pig feed has yet to be identified. In 2011, Isaacs et al. ${ }^{121}$ claimed that Staurospira could replace $7.5 \%$ of soybean meal in diets for weanling pigs. Making further progress, Manor et al. ${ }^{122}$ later established that inclusion of $15 \%$ of microalgal-biomass did not change growth performance of non-anemic pigs.

In lactating dairy cows, recent nutritional trials indicated that a cocktail of microalgae species can replace soybean meal as a source of proteins. ${ }^{123}$ In particular, the inclusion of Spirulina led to increased milk fat concentration, and the inclusion of Nannochloropsis in cow diets resulted in favorable omega-6:omega3 ratio for human nutrition "and a fourfold increase in milk EPA [eicosapentaenoic acid] concentration without adverse effects on milk fat production'.

Research suggests that the digestibility of microalgae in animal diets will depend on the resistance of the cell wall (their cell wall structure). Various treatment methods and biorefinery models can be applied in the downstream processing of algalbiomass which would rupture the cell wall for protein release and separation (i.e., increase protein bioavailability), thus allowing the use of microalgae as a "drop-in feed" ingredient (which then feed providers could introduce into the fodder mix). No single method is optimal for all microalgae species. It is beyond the scope of this paper to discuss these methods (see Chronakis et al. ${ }^{124}$ and Vermuë et al. ${ }^{125}$ ).

Still, microalgae remain an under-exploited "crop.",55,126,127

Recent research illustrates that the discourse of sustainable feed sources has expanded: the discussion is no longer confined to the nutritional viability of algae as feed, it now also explores sustainable, technically-attainable feed production systems.

The integrated system at the center of this study currently grows a natural strain of the green marine microalgae Nannochloropsis oculata. ${ }^{128-130}$ The system could cultivate all six known Nannochloropsis species (see Ma et al.) ${ }^{131}$ as well as any other microalgae strain, marine or fresh-water (including Spirulina).

The nutritional profile of $N$. oculata bears similarity to that of soybean. ${ }^{132}$ The composition of $N$. oculata is about $40 \%$ proteins (against 36\% in soybean), 29\% carbohydrate (fiber, sugar and polysaccharides), $15 \%$ fats (including omega-3 fatty acids), $14 \%$ minerals (including trace minerals) and 2\% chlorophyll and carotenoids. Its essential amino acids composition is $9 \%$ Leucine (3\% in soy), $8 \%$ Lysine (2.7\% in soy), 6\% Arginine (3.1\% in soy), $6 \%$ Valine (2\% in soy), $5 \%$ Threonine $(1.7 \%$ in soy), $5 \%$ Phenylalanine (2.1\% in soy), $4 \%$ Isoleucine $(1.9 \%$ in soy), $2 \%$ Methionine $(0.5 \%$ in soy) and $2 \%$ Histidine $(1 \%$ in soy). ${ }^{133}$

$N$. oculata is cultured in a controlled-environment agriculture (CEA) system: artificially lit, geothermal energy-based, with zero pesticides and herbicides, and fertilizer-efficient. LED technology is used to achieve high photosynthetic photon flux at the wavelengths of photosynthetic interest. The novel configuration shown in Fig. 2 operates in a "no-spill zone" site, and the cultivation facility employs an evaporative oxidization system for sanitation and crop protection, with no harmful environmental consequences.

The photosynthetic photon flux density (PPFD) ${ }^{134}$ of the system averages over $750\left(\mu \mathrm{mol}\right.$ per $\mathrm{m}^{2}$ per second $){ }^{135}$ For comparison, hydroponic lettuce (Lactuca sativa L.) achieves good growth results under treatments of high light intensity (LED) of 290 PPFD. ${ }^{136}$

Since the microalgae culture grows in a liquid medium, material handling and mechanization costs are anticipated to be low relative to terrestrial crops (for instance, soybean cultivation is labor and machine intensive).

The microalgae LED-PBR cultivation system is modularly divided into Production Units (PUs). Data from in situ measurements, triangulated with third parties, indicate that each PU requires $159.2 \mathrm{kWh}\left(\mathrm{LED}, \mathrm{CO}_{2} \text { and operations combined }\right)^{137}$ to cultivate $1 \mathrm{~kg}$ of algal biomass (DM). In each PU, culture is grown in liquid medium of $14.4 \mathrm{~m}^{3}$. In local conditions, this volume of water is of a potable water source, and is replaced entirely once every two months (6 times per annum). The closed system presents no opportunity for water loss through evaporation. Each PU uses zero hectares of productive, arable land, and occupies approximately $130 \mathrm{~m}^{2}$ of non-productive land (this figure accounts for PU and Direct Air Capture unit; the calculation excludes energy production area). A PU produces approximately $10,500 \mathrm{~kg}$ (DM) of biomass per annum.

In the cultivation process, $0.084 \mathrm{~kg}$ of dipotassium phosphate $\left(\mathrm{K}_{2} \mathrm{HPO}_{4}\right)$ and $0.65 \mathrm{~kg}$ of sodium nitrate $\left(\mathrm{NaNO}_{3}\right)$ are consumed per 1 kilogram of biomass. The cultivation of $1 \mathrm{~kg}$ of biomass requires approximately $2 \mathrm{~kg}$ of $\mathrm{CO}_{2}$-equivalent. The $\mathrm{CO}_{2}$ emissions balance, calculated for each PU by third parties, stands at a net negative of -0.93 ton of $\mathrm{CO}_{2}$-equivalent per ton (DM) of biomass (excluding fertilizers). No pesticides and herbicides are involved in the production process.

\section{Comparison of Land and Water Uses}

A Production Unit currently uses about $130 \mathrm{~m}^{2}$ of nonproductive lands to cultivate $10,500 \mathrm{~kg}$ of biomass per annum (Fig. 3). Fresh water utilization is based on medium replacements. This translates into $8.23 \mathrm{~L}$ of fresh water per $\mathrm{kg}$ of dry weight, ash-free (6.8\% ash), algal biomass (Fig. 4). A largescale commercial production site is currently under construction in Hellisheiði geothermal park. Figures used for comparison are based on production potential and on data provided above.

\section{Discussion}

Meeting an expected increase in global demand for animal products requires innovative technological platforms for the culture of fully sustainable animal feed.

Such innovations should part from the common prescription of yield intensification and cropland expansion which draw on an already limited supply of arable lands and fresh water. New platforms should attempt to approach carbon neutrality (net zero 


\section{TZACHOR}

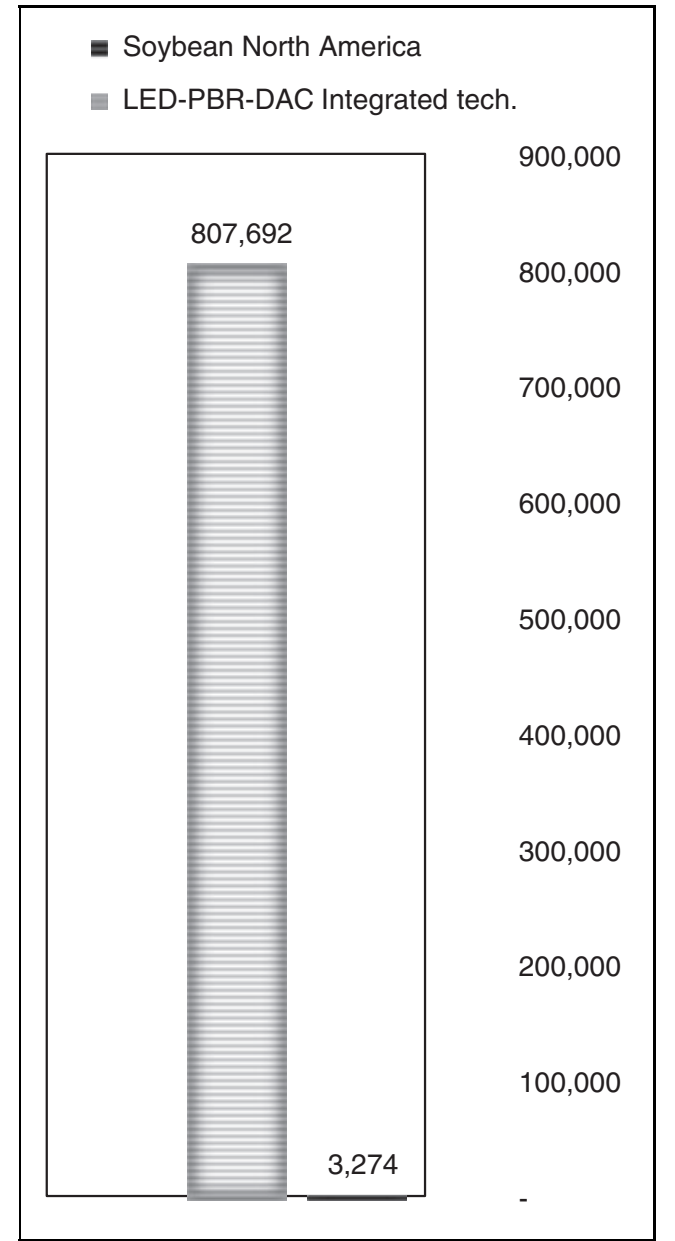

Fig. 3. Areal yield (land footprint) comparison: LED-PBR-DAC and US soybean $(\mathrm{kg} / \mathrm{ha})$. This shows a nearly 250 -fold higher output (yield) for microalgae cultured in the novel configuration (geothermal powered LED-PBR-DAC) than for soybean.

carbon footprint), net zero water use, zero net fertile-land degradation, and zero agro-waste by regulating resources life-cycles so that they are optimally used with no harmful disposal.

This paper presented the findings of research into one novel configuration of four technologies employed to cultivate a sustainable soybean equivalent feed ingredient. This configuration is technically feasible and resource-efficient. As nutritional research advances, new data are likely to emerge as to the digestibility of strains of microalgae used for animal-feed. Current research already suggests that a variety of microalgae, used alone or in combination (Spirulina platensis; Chlorella vulgaris; Nannochloropsis gaditana) can complement the use of soy in animal husbandry and thus mitigate some of the future demand.

This innovative configuration sets the land productivity of the LED-PBR-DAC system at a potential $807,692 \mathrm{~kg}$ of biomass per hectare per year (Fig. 3). The integrated system's water consumption is 8.23 liters of potable water per kilogram of biomass, at a high cell density of above $10 \mathrm{~g}$ (ash-free dry weight; $6.8 \%$

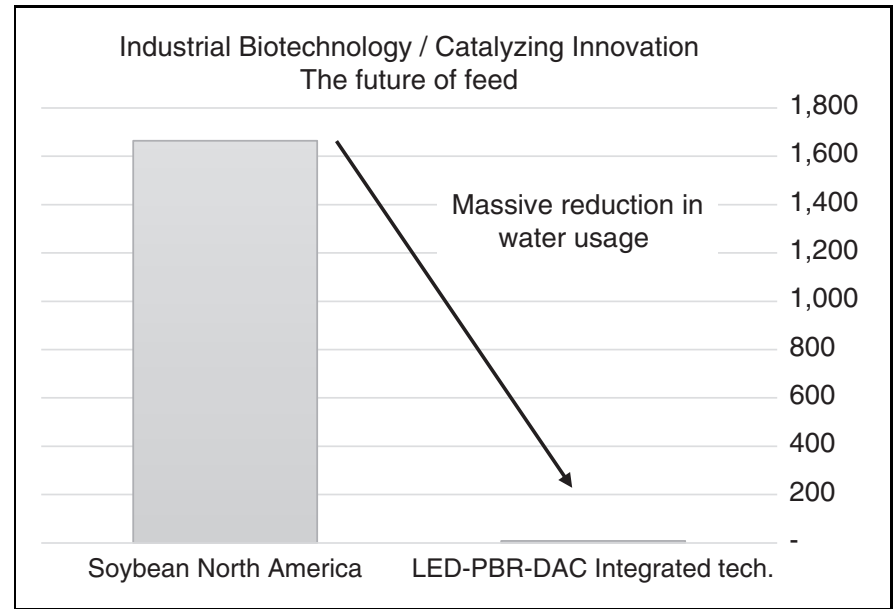

Fig. 4. Fresh water requirements (water footprint) comparison: LED-PBR-DAC and soybean (L/kg). This shows a nearly 200 -fold higher water footprint (fresh water use) soybean than for microalgae cultured in the novel configuration (geothermal powered LED-PBR-DAC).

ash) per liter of water. ${ }^{138}$ These figures represent a reduction of arable land and fresh water footprint of a feed-source cultivated in LED-PBRs by a factor of over 200, compared with the land and water footprint of soybean cultivation (Fig. 4).

With best available technologies, these productivity rates could only be achieved for microorganisms, and microalgae in particular. As Walsh et al. ${ }^{139}$ noted, microalgae "grows 10 times more rapidly than terrestrial plants... it doesn't compete with other crops for land... it doesn't require fresh water... it can be fertilized more efficiently than land crops... it avoids wasteful fertilizer runoff, and downstream eutrophication associated with modern agriculture",

Furthermore, cultivating unicellular "crops" assists in achieving zero agro-waste, as no energy and matter are invested in developing non-edible external plant architecture (e.g. roots, stems, leaves) characterizing multicellular staple crops.

From a techno-operational perspective, LED-PBR-DAC feed production potential is linked primarily to available energy (mainly in the form of light). If cultivation is to be sustainable, then a clean energy source is required. If it is to maintain production at constant rates, then the energy source must not be susceptible to intermittencies. These systems' properties call for further research on the feed production potential of the integrated system utilizing additional energy sources, mainly hydropower.

While the assessments in this paper are focused strictly on environmental considerations, other economic factors play a critical role in developing alternative, scalable and economicallysustainable future food and feed options. Accounting for these factors warrants further techno-economic analyses.

\section{Author Disclosure Statement}

The author does not work for, consult, own shares in or receive funding from any organization that would benefit from this article. The author has no relevant affiliations beyond his 
academic appointment. The author has no other financial and/or non-financial interests in relation to the study described in the article that could undermine the objectivity and integrity of data presentation, analysis and interpretation.

\section{Acknowledgments}

Data obtained with the generous assistance of Dagný Hauksdóttir, Verkefnastjóri Jarðhitagarðs ON Power, Iceland; Daniel Egger, Climeworks, Zurich, Switzerland; Sam Couture, Algaennovation, Iceland; Ari Ingimundarson, Mannvit, Iceland; Gunnar Tryggvason, Iceland; and Kevin Dillman, Orkuveita Reykjavíkur (OR, Reykjavík Energy), Iceland, between November 2018 and February 2019.

This paper was made possible through the support of The Centre for the Study of Existential Risk (CSER), an interdisciplinary research centre at CRASSH within the University of Cambridge. This paper is part of the Food Security and Global Catastrophic Risks Project at CSER, Cambridge, dedicated to explore dependencies and distortions in the food system, to understand what shocks might threaten global food security, what the consequences of such shocks may be, and how society can work to mitigate these risks.

Asaf Tzachor is Lead Researcher for Global Food Security and Research Associate at the Center For the Study of Existential Risk (CSER), at the University of Cambridge (Cambridge, UK), and Fellow of the Royal Geographical Society (UK). Email: at875@cam.ac.uk.

\section{REFERENCES}

1. United Nations (2015). World Population Prospects: The 2015 Revision, Key Findings and Advance Tables. ESA/P/WP.241. United Nations, New York, 2015.

2. United Nations (2018). Revision of World Urbanization Prospects. United Nations, New York, 2018. Available at: https://www.un.org/development/desa/ publications/2018-revision-of-world-urbanization-prospects.html (Last accessed March 2019).

3. Kharas $\mathrm{H}$. The unprecedented expansion of the global middle class. An update (2017). Brookings Institute, Washington DC. Available at: https:// www.brookings.edu/wp-content/uploads/2017/02/global_20170228_globalmiddle-class.pdf (Last accessed March 2019

4. Smil V. Feeding the World. A Challenge for the Twenty-First Century. Cambridge, MA, MIT Press, 2001.

5. Alexandratos N, Bruinsma J. (2012). World agriculture towards 2030/2050: the 2012 revision (Vol. 12, No. 3). FAO, Rome: ESA Working paper. Available at: http://www.fao.org/3/a-ap106e.pdf (Last accessed March 2019).

6. Food and Agricultural Organization (2013). The State of Food Insecurity in the World: The Multiple Dimensions of Food Security, the Food and Agriculture Organization of the United Nations, Rome.

7. Food and Agricultural Organization (2017). The State of Food Security and Nutrition in the World, the Food and Agriculture Organization of the United Nations, Rome.

8. Speedy AW. Overview of world feed protein needs and supply (2016). Animal Production and Health Division. The Food and Agriculture Organization of the United Nations, Rome. Available at: http://www.fao.org/tempref/docrep/fao/ 007/y5019e/y5019e02.pdf (Last accessed March 2019).

9. Springmann $M$, Clark M, Mason-D'Croz D. Options for keeping the food system within environmental limits. Nature 2018;562:519-525.
10. World Wildlife Fund (2017). Appetite for Destruction, World Wildlife Fund, Washington, DC. Available at: https://wwf.org.uk/updates/appetite-fordestruction (Last accessed March 2019).

11. Food and Agricultural Organization. The future of food and agricultureAlternative pathways to 2050 (2018). The Food and Agriculture Organization of the United Nations, Rome. Available at: http://www.fao.org/publications/ fofa (Last accessed March 2019).

12. Godfray HCJ, Beddington JR, Crute IR, et al. Food security: The challenge of feeding 9 billion people. Science 2010;327(5967):812-818.

13. Access to food does not imply food intake.

14. Food and Agricultural Organization (2017b), More Fuel for the Food/Feed Debate, Livestock Policy. The Food and Agriculture Organization of the United Nations, Rome. Available at: http://www.fao.org/ag/againfo/home/en/ news_archive/2017_More_Fuel_for_the_Food_Feed.html (Last accessed March 2019).

15. Mottet A, de Haan C, Falcucci A, et al. Livestock: On our plates or eating at our table? A new analysis of the feed/food debate. Global Food Security 2017;14: $1-8$.

16. Fischer RA, Byerlee D, Edmeades G. Crop yields and global food security. ACIAR: Canberra ACT 2014;8-11.

17. Food and Agricultural Organization (2017). Food and agriculture data: Production and inputs. FAO, Statistics Division, Rome. Available at: http:// fao.org/faostat/en/\#data (Last accessed February 2019).

18. Fischer et al. (2014) noted that figures for land area, production and yield carry uncertainty.

19. Ainsworth EA, Yendrek CR, Skoneczka JA, Long SP. Accelerating yield potential in soybean: Potential targets for biotechnological improvement. Plant Cell Environ 2012;35(1):38-52.

20. WWF. The Growth of Soy: Impacts and Solutions. WWF International, Gland, Switzerland (2014). Available at: http://awsassets.wwfdk.panda.org/ downloads/wwf_soy_report_final_jan_19.pdf (Last accessed March 2019).

21. Srinivasan $V$, Kumar $P$, Long SP. Decreasing, not increasing, leaf area will raise crop yields under global atmospheric change. Glob Chang Biol 2017;23(4): 1626-1635.

22. Cassidy ES, West PC, Gerber JS, Foley JA. Redefining agricultural yields: From tonnes to people nourished per hectare. Environ Res Lett 2013;8(3):034015.

23. Global Forest Atlas. Soy Agriculture. Land Use, Industrial Agriculture (2019). Available at: https://globalforestatlas.yale.edu/land-use/industrial-agriculture/ soy-agriculture (Last accessed March 2019).

24. Versus approximately $10 \%$ protein and $5 \%$ oil in maize.

25. Wang JP, Hong SM, Yan L, et al. The evaluation of soybean meals from 3 major soybean-producing countries on productive performance and feeding value of pig diets. J Anim Sci 2011;89(9):2768-2773.

26. Gonzalez Mateos $G$, Gonzalez M, Sueiro $S$, et al. Differences among origins on nutritional and quality parameters of soybean meal. Poult Sci 2011;90(Suppl 1): 57.

27. US Soybean Export Council. The Nutritional Value of U.S. Soybean Meal (2015). Available at: https://ussec.org/wp-content/uploads/2015/10/ 20120123-Nutritional-value-white-paper-1.pdf (Last accessed March 2019).

28. In arguing for US soybean higher nutritional values, the USSEC referred to "an extensive comparative study of soybeans from around the world... conducted from 2007 to 2011, with more than 430 samples of soybean meal from Argentina, Brazil, and the United States... samples were obtained at shipping ports or country of origin and analyzed for proximal analysis, amino acid content, sugars, and mineral content" (ibid, 2015:4). The US Soybean Export Council noted (2015:4) that "universities and research institutions around the world have demonstrated the superior amino acid profile and digestibility of the U.S. soybean meal". Data is cited from United States Department of Agriculture, Agricultural Research Service, National Nutrient Database for Standard Reference Legacy Release. United States Department of Agriculture, 


\section{TZACHOR}

Agricultural Research Service (2019). National Nutrient Database for Standard Reference Legacy Release, retrieved 18 February 2019. Available at: https:// ndb.nal.usda.gov/ndb/foods/show/4845?fgcd $=$ \&tmanu $=$ \&tlfacet=\&tformat $=$ Fulletcount=\&max=35\&toffset=\&tsort=\&tqlookup=16108 (Last accessed March 2019).

29. Irrigation is applied in Nebraska and Arkansas, for instance.

30. Rotated with rice in Asia, with maize and wheat in the US and with maize in Brazil.

31. Animal Production and Health Division and the Livestock Environmental Assessment and Performance (LEAP) Partnership, 2017, FAO. Available at: http://www.fao.org/partnerships/leap/en/ (Last accessed March 2019).

32. Green water refers to rainwater (excluding runoff). Grey water refers to pollution (freshwater that assimilates the load of pollutants (associated with the cultivation method). Blue water refers to surface and groundwater resources. In all three categories, water consumed would otherwise become available ground-surface water body in the catchment basin (see Mekonnen and Hoekstra, 2010).

33. Mekonnen MM, Hoekstra AY. The green, blue and grey water footprint of farm animals and animal products, Vol. 1 (2010). Delft: UNESCO-IHE Institute for water Education.

34. Sinclair TR, Messina CD, Beatty A, Samples M. Assessment across the United States of the benefits of altered soybean drought traits. Agron J 2010;102: 475-482.

35. Summarizing over 1,000 studies researching possible climate change impacts on the four global staple crops, Porter et al. (2014) determined that climate change could dramatically reduce soybean yields in the long-term. Porter JR, Xie L, Challinor AJ, et al. Food security and food production systems. In IPCC. Climate Change 2014: Impacts, Adaptation, and Vulnerability. Part A: Global and Sectoral Aspects. Contribution of Working Group II to the Fifth Assessment Report of the Intergovernmental Panel on Climate Change, 2014, pp. 485-533.

36. Rockström J, Steffen WL, Noone K, et al. Planetary boundaries: Exploring the safe operating space for humanity. Ecol Soc 2009;14(2).

37. Geiger $F$, Bengtsson J, Berendse $F$, et al. Persistent negative effects of pesticides on biodiversity and biological control potential on European farmland. Basic Appl Ecol 2010;11(2):97-105.

38. Lindenmayer D, Cunningham S, Young A. Land use intensification: Effects on agriculture, biodiversity and ecological processes. Collingwood, Australia, CSIRO publishing, 2012.

39. Nearing MA, Xie Y, Liu B, Ye Y. Natural and anthropogenic rates of soil erosion. Int Soil Water Conserv Res 2017;5(2):77-84.

40. Deininger $K$, Byerlee $D$. Rising global interest in farm land: Can it yield sustainable and equitable benefits? World Bank: Washington, DC, 2011.

41. Fearnside PM. Soybean cultivation as a threat to the environment in Brazil. Environ Conserv 2001;28(1):23-38.

42. Morton DC, DeFries RS, Shimabukuro YE, et al. Cropland expansion changes deforestation dynamics in the southern Brazilian Amazon. Proc Natl Acad Sci USA 2006;103(39):14637-14641.

43. Barona E, Ramankutty N, Hyman G, Coomes OT. The role of pasture and soybean in deforestation of the Brazilian Amazon. Environ Res Lett 2010;5(2): 024002.

44. Macedo MN, DeFries RS, Morton DC et al. Decoupling of deforestation and soy production in the southern Amazon during the late 2000s. Proc Natl Acad Sci USA 2012;109(4):1341-1346.

45. Rautner M, Leggett M, Davis F. (2013). The Little Book of Big Deforestation Drivers, Global Canopy Programme: Oxford.

46. Long SP, Ort DR. More than taking the heat: Crops and global change. Curr Opin Plant Biol 2010;13:241-248.

47. Ray DK, Mueller ND, West PC, Foley JA. Yield trends are insufficient to double global crop production by 2050. PLOS ONE 2013;8:e66428.
48. Long SP. We need winners in the race to increase photosynthesis in rice, whether from conventional breeding, biotechnology or both. Plant Cell Environ 2014;37:19-21.

49. Tweetin SR, Thompson L. Long-term global agricultural output supplyDemand balance, and real farm and food prices. Farm Policy J 2009; 61:1-15.

50. Long S., University of Illinois College of Agricultural, Consumer and Environmental Sciences (ACES), 2016, Soybean plants with fewer leaves yield more, accessed at February 14, 2019. Available at: https://sciencedaily.com/ releases/2016/11/161119091525.htm (Last accessed March 2019).

51. Lambin EF, Meyfroidt P. Global land use change, economic globalization, and the looming land scarcity. Proc Natl Acad Sci USA 2011;108(9):3465-3472.

52. Pimentel $D$, Harvey $C$, Resosudarmo $P$, et al. Environmental and economic costs of soil erosion and conservation benefits. Science 1995;267(5201): 1117-1123.

53. Pimentel D. Soil erosion: A food and environmental threat. Environment, development and sustainability, 2006;8(1):119-137.

54. Quinton JN, Govers G, Van Oost K, Bardgett RD. The impact of agricultural soil erosion on biogeochemical cycling. Nature Geosci 2010;3(5):311.

55. Bleakley S, Hayes M. Algal proteins: Extraction, application, and challenges concerning production. Foods 2017;6(5):33.

56. Nelson GC, Rosegrant MW, Palazzo A, Gray I, Ingerstoll C, Robertson R. Food security, farming, and climate change to 2050: Scenarios, results, policy options. Research Monograph (2010). International Food Policy Research Institute, Washington, DC.

57. Tilman D, Balzer C, Hill J, Befort BL. Global food demand and the sustainable intensification of agriculture. Proc Natl Acad Sci USA 2011;108:2026020264.

58. Griggs D, Stafford-Smith M, Gaffney 0, et al. Policy: Sustainable development goals for people and planet. Nature 2013;495(7441):305.

59. Brown C, Alexander P, Arneth A, Holman I, Rounsevell M. Achievement of Paris climate goals unlikely due to time lags in the land system. Nature Climate Change 2019;9:203-208.

60. Wilcox JR. Sixty years of improvement in publicly developed elite soybean lines. Crop Sci 2001;49:1711-1716.

61. De Buin JL, Pederson P. Yield improvement and stability for soybean cultivars with resistance to Heterodera glycines Ichinohe. Agron J 2008;100:13541359.

62. Egli DB. Soybean yield trends from 1972 to 2003 in mid-western USA. Field Crops Res 2008;106:53-59.

63. Egli DB. Time and the productivity of agronomic crops and cropping systems. Agron J 2011;103:743-750.

64. Baulcombe D, Crute I, Davies B, et al. Reaping the benefits: Science and the sustainable intensification of global agriculture (2009). The Royal Society. Available at: https://royalsociety.org/ /media/royal_society_content/policy/ publications/2009/4294967719.pdf (Last accessed March 2019).

65. Sadras VO, Calderini DF. Crop physiology: Applications for genetic improvement and agronomy. Elsevier: London, 2009.

66. Sanchez P, Denning GL, Nziguheba G. The African Green Revolution moves forward. Food Security 009;1:37-44.

67. Connor DJ, Loomis RS, Cassman KG. Crop ecology: Productivity and management in agricultural systems. Cambridge University Press: Cambridge, UK, 2011.

68. Linehan V, Thorpe $\mathrm{S}$, Gunning-Trant $\mathrm{C}$, et al. Global food production and prices to 2050: Scenario analysis under policy assumptions. Conference paper 13.6 Australian Bureau of Agricultural and Resource Economics and Sciences: Canberra, 2013

69. Lobell DB, Baldos U, Hertel TW. Climate adaptation as mitigation: The case of agricultural investments. Environ Res Lett 2013;8:015012. 


\section{THE FUTURE OF FEED}

70. Rosegrant M, Tokguz S, Bhandary P. Future of the global food economy: Alternative scenarios for supply, demand, and prices. In: Barrett CB, ed., Food security and its implications for global stability, Oxford, UK, Oxford University Press, 2013;35-63.

71. FAO. Sustainable Crop Production Intensification. Agriculture, Plant Production and Protection (2019). Available at: http://fao.org/agriculture/ crops/thematic-sitemap/theme/spi/en/ (Last accessed March 2019).

72. Parodi A, Leip A, De Boer IJM, et al. The potential of future foods for sustainable and healthy diets. Nature Sustain 2018;1(12):782.

73. Tollefson J. Sucking carbon dioxide from air is cheaper than scientists thought. Nature 2018;558(7709):173.

74. Pulz 0. Photobioreactors: Production systems for phototrophic microorganisms. Appl Microbiol Biotechnol 2001;57(3):287-293.

75. Suh IS, Lee CG. Photobioreactor engineering: Design and performance. Biotechnol Biopr Eng 2003;8(6):313.

76. Huang J, Li Y, Wan M, et al. Novel flat-plate photobioreactors for microalgae cultivation with special mixers to promote mixing along the light gradient. Bioresour Technol 2014;159:8-16.

77. Lee $\mathrm{CG}$, Palsson $\mathrm{B} \emptyset$. High-density algal photobioreactors using light-emitting diodes. Biotechnol Bioeng 1994;44(10):1161-1167.

78. Mori K. Photoautotrophic bioreactor using visible solar rays condensed by Fresnel lenses and transmitted through optical fibers. Biotechnol Bioeng Symp 1985;15:331-345

79. Ogbonna JC, Yada $H_{\text {, Masui }} H_{\text {, Tanaka }}$ H. A novel internally illuminated stirred tank photobioreactor for large-scale cultivation of photosynthetic cells. J Ferment Bioeng 1996;82(1):61-67.

80. Straka F, Doucha J, Crha J, Livansky K. Flue-gas $\mathrm{CO}_{2}$ as a source of carbon in closed cycle with solar culture of microalgae. Abstracts of the 4th European workshop on biotechnology of microalgae. Bergholz-Rehbrücke, Germany, 2000

81. Edmundson $S$, Huesemann $M$, Kruk $R$, et al. Phosphorus and nitrogen recycle following algal bio-crude production via continuous hydrothermal liquefaction. Algal Res 2017;26:415-421.

82. Janssen M, Tramper J, Mur LR, Wijffels RH. Enclosed outdoor photobioreactors: Light regime, photosynthetic efficiency, scale-up, and future prospects. Biotechnol Bioeng 2003;81(2):193-210.

83. Kirk JT (1994). Light and photosynthesis in aquatic ecosystems. Cambridge university press. Cambridge, UK.

84. Schulze PS, Barreira LA, Pereira HG, Perales JA, Varela JC. Light emitting diodes (LEDs) applied to microalgal production. Trends Biotechnol 2014;32(8):422430

85. Darko E, Heydarizadeh P, Schoefs B, Sabzalian MR. Photosynthesis under artificial light: The shift in primary and secondary metabolism. Philos Trans $R$ Soc Lond B Biol Sci 2014;369(1640):20130243.

86. Blanken W, Cuaresma M, Wijffels RH, Janssen M. Cultivation of microalgae on artificial light comes at a cost. Algal Res 2013;2(4):333-340.

87. Ooms MD, Dinh CT, Sargent EH, Sinton D. Photon management for augmented photosynthesis. Nature Comm 2016;7:12699.

88. See Ooms et al. (2016) for a review of advances in LED efficiency; energy input to photon flux output, and affordability.

89. LED-based CEA systems allow the management of the light spectrum, light distribution and cellular light utilization, thereby intensifying production further.

90. Kumar R. Air Products and Chemicals Inc. 8 December 1987. Removal of water and carbon dioxide from atmospheric air. United States Patent Publication $4,711,645$

91. Ranjan M, Herzog HJ. Feasibility of air capture. Energ Procedia 2011;4:28692876.

92. Stolaroff JK, Keith DW, Lowry GV. Carbon dioxide capture from atmospheric air using sodium hydroxide spray. Environ Sci Technol 2008;42(8);27282735.
93. Mahmoudkhani $\mathrm{M}$, Keith DW. Low-energy sodium hydroxide recovery for $\mathrm{CO}_{2}$ capture from atmospheric air-Thermodynamic analysis. Int J Greenhouse Gas Control 2009;3(4):376-384.

94. Keith DW, Ha-Duong $\mathrm{M}_{1}$ Stolaroff JK. Climate strategy with $\mathrm{CO}_{2}$ capture from the air. Climatic Change 2006;74(1-3);17-45

95. Lackner KS, Brennan S, Matter JM, Park AHA, Wright A, Van Der Zwaan B. The urgency of the development of $\mathrm{CO}_{2}$ capture from ambient air. Proc Natl Acad Sci USA 2012;109(33):13156-13162.

96. Service RF. Cost plunges for capturing carbon dioxide from the air (2018). Available at: https://sciencemag.org/news/2018/06/cost-plunges-capturingcarbon-dioxide-air (Last accessed March 2019).

97. Baciocchi R, Storti G, Mazzotti M. Process design and energy requirements for the capture of carbon dioxide from air. Chem Eng Process: Process Intensification 2006;45(12):1047-1058.

98. Nikulshina $V$, Gebald $C$, Steinfeld A. $\mathrm{CO}_{2}$ capture from atmospheric air via consecutive $\mathrm{CaO}$-carbonation and $\mathrm{CaCO}_{3}$-calcination cycles in a fluidized-bed solar reactor. Chem Eng J 2009;146(2):244-248.

99. For a complete technical analysis of Direct Air Capture (DAC) technology see Climeworks (2018). Available at: http://climeworks.com/climeworks-andcarbfix2-the-worlds-first-carbon-removal-solution-through-direct-air-capture/

100. Barbier, E. Geothermal energy technology and current status: An overview. Renew Sustain Energ Rev 2002;6(1-2);3-65.

101. For a further discussion on environmental impacts of geothermal energy; fluids, air pollution, water pollution, land subsidence, see Barbier (2002).

102. ON Power. The Power of Iceland Energy. Available at: http://onpower.is/ (Last accessed March 2019).

103. European Investment Bank. Hellisheiði Power Plant Environmental Impact Assessments (2008). Available at: http://eib.org/attachments/pipeline/ 20080135_nts1_en.pdf (Last accessed March 2019).

104. Shields RJ, Lupatsch I. Algae for aquaculture and animal feeds. J Anim Sci 2012:21:23-37.

105. Borowitzka MA. High-value products from microalgae-Their development and commercialisation. J Appl Phycol 2013;25(3):743-756.

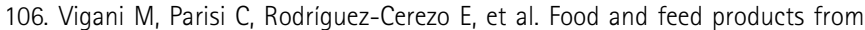
micro-algae: Market opportunities and challenges for the EU. Trends Food Sci Technol 2015;42(1):81-92.

107. Buono S, Langellotti AL, Martello A, Rinna F, Fogliano V. Functional ingredients from microalgae. Food Funct 2014;5(8):1669-1685.

108. Sousa I, Gouveia L, Batista AP, Raymundo A, Bandarra NM. Microalgae in novel food products. Food Chem Res Dev 2008;75-112.

109. Pulz O, Gross W. Valuable products from biotechnology of microalgae. Appl Microbiol Biotechnol 2004;65(6):635-648.

110. Hemaiswarya S, Raja R, Kumar RR, Ganesan V, Anbazhagan C. Microalgae: A sustainable feed source for aquaculture. World J Microbiol Biotechnol 2011; 27(8):1737-1746

111. Kuehnle A. Sustaining the future with algae. Ind Biotechnol 2017;13(5):217-218.

112. Moomaw W, Berzin I, Tzachor A. Cutting out the middle fish: Marine microalgae as the next sustainable omega-3 fatty acids and protein source. Ind Biotechnol 2017;13(5):234-243.

113. Gatrell S, Lum K, Kim J, Lei XG. Nonruminant nutrition symposium: Potential of defatted microalgae from the biofuel industry as an ingredient to replace corn and soybean meal in swine and poultry diets. J Anim Sci 2014;92(4): 1306-1314.

114. Gatrell SK, Kim J, Derksen TJ, O'Neil EV, Lei XG. Creating $\omega$-3 fatty-acidenriched chicken using defatted green microalgal biomass. J Agric Food Chem 2015;63(42):9315-9322.

115. Kim J, Magnuson A, Tao L, Barcus M, Lei XG. Potential of combining flaxseed oil and microalgal biomass in producing eggs-enriched with $n-3$ fatty acids for meeting human needs. Algal Res 2016;17:31-37. 


\section{TZACHOR}

116. Austic RE, Mustafa A, Jung B, Gatrell S, Lei XG. Potential and limitation of a new defatted diatom microalgal biomass in replacing soybean meal and corn in diets for broiler chickens. J Agric Food Chem 2013;61(30);7341-7348.

117. Becker W. Microalgae in human and animal nutrition. In: Richmond A (ed), Handbook of Microalgal Culture: Biotechnology and Applied Phycology, Vol. 312, Hoboken, NJ, Blackwell Publishing, 2004.

118. Evans AM, Smith DL, Moritz JS. Effects of algae incorporation into broiler starter diet formulations on nutrient digestibility and 3 to $21 \mathrm{~d}$ bird performance. J Appl Poultry Res 2015;24(2):206-214.

119. Altmann B, Neumann C, Velten S, Liebert F, Mörlein D. Meat quality derived from high inclusion of a micro-alga or insect meal as an alternative protein source in poultry diets: A pilot study. Foods 2018;7(3):34.

120. Yap TN, Wu JF, Pond WG, Krook L. Feasibility of feeding Spirulina maxima, Arthrospira platensis or Chlorella sp. to pigs weaned to a dry diet at 4 to 8 days of age. Nutr Rep Int 1982;25:543-552.

121. Isaacs $R$, Roneker KR, Huntley M, Lei XG. A partial replacement of soybean meal by whole or defatted algal meal in diet for weanling pigs does not affect their plasma biochemical indicators. J Anim Sci 2011;89(Suppl 1):723.

122. Manor ML, Kim J, Derksen TJ, et al. Defatted microalgae serve as a dual dietary source of highly bioavailable iron and protein in an anemic pig model. Algal Res 2017;26:409-414.

123. Lamminen $M$, Halmemies-Beauchet-Filleau A, Kokkonen $T$, Jaakkola $S$, Vanhatalo A. Different microalgae species as a substitutive protein feed for soya bean meal in grass silage based dairy cow diets. Anim Feed Sci Technol 2019;247:112-126.

124. Chronakis IS, Madsen M. Algal proteins. In: Phillips GO, Williams PA (eds), Handbook of food proteins. Woodhead Publishing Series in Food Sciences, Technology and Nutrition, Sawston, Cambridge, 2011, p. 353-394.

125. Vermuë MH, Eppink MHM, Wijffels RH, Van Den Berg C. Multi-product microalgae biorefineries: From concept towards reality. Trends Biotechnol 2018;36(2):216-227.

126. Smith VH. Progress in algae as a feedstock for bioproducts. Ind Biotechnol 2014;10(3):159-161.

127. Tan W. ROI-integrated commercialization: An adaptive pathway for microalgae technology. Ind Biotechnol 2018;14(1):17-24.

128. For a morphological analysis of Nannochloropsis see Ma et al., 2016.

129. In contrast to other microalgae cultivated for food purposes, namely Chlorella, nannochloropsis oculata involves no fermentation, which sets its sustainability performance apart. Turning plant sugars into plant proteins requires sugar cultivation as a primary factor of production, which ties the Chlorella culture method and process-through sugar-to fresh water, arable lands, and a host of additional limiting factors. It does little to reduce the environmental footprint of the food system. This requires a further, separate, discussion.

130. According to Ma et al. (2016) "Nannochloropsis is a promising unicellular factory for lipid production. Nannochloropsis is considered as a potential oleaginous model microalga because of the great photosynthetic efficiency, high lipid productivity, well-established genetic toolbox and relatively mature technology for outdoor cultivation systems on a large scale".

131. Ma XN, Chen TP, Yang B, Liu J, Chen F. Lipid production from Nannochloropsis. Marine Drugs 2016;14(4):61.

132. Analysis of nutritional composition was carried out by New Jersey Feed Lab and Eurofins Food Testing Ireland.

133. Leow S, Witter JR, Vardon DR, Sharma BK, Guest JS, Strathmann TJ. Prediction of microalgae hydrothermal liquefaction products from feedstock biochemical composition. Green Chem 2015;17(6):3584-3599.

134. Photosynthetic photon flux density (PPFD) is the photon flux density of PAR. PAR is photosynthetically active radiation a light source gives. PAR defines the type of light needed to support photosynthesis, while photosynthetic photon flux determines the amount of PAR that is created by a lighting system each second.

135. See Carruthers TJ, Longstaff BJ, Dennison WC, Abal EG, Aioi K. Measurement of light penetration in relation to seagrass. Global Seagrass Research Methods, Amsterdam, Elsevier 2001;369-392.

136. Kang JH, KrishnaKumar S, Atulba SLS, Jeong BR, Hwang SJ. Light intensity and photoperiod influence the growth and development of hydroponically grown leaf lettuce in a closed-type plant factory system. Horticult Environ Biotechnol 2013;54(6):501-509.

137. Figures for DAC systems not connected to geothermal energy source, where water need to be heated.

138. A combination of the system's high photon flux density and a short light path $(5 \mathrm{~cm}$ thick panels, LED-illuminated from both sides) enables a steady state operational cell density of above 10 grams AFDW, per liter, where the harvest rate is set to match the growth rate.

139. Walsh MJ, Van Doren LG, Sills DL, et al. Algal food and fuel coproduction can mitigate greenhouse gas emissions while improving land and water-use efficiency. Environ Res Lett 2016;11(11):114006. 